Volume 32, 2022

http://journals.sfu.ca/dwr

\title{
Editorial
}

\section{Editorial Reflections: The Places and Identities of Writing and Writers}

Kim Mitchell

Red River College

Sean Zwagerman

Simon Fraser University

Ten years ago, in her 2012 keynote address at the annual Canadian Association for the Study of Discourse and Writing (CASDW) conference, Louise Wetherbee Phelps addressed the formation of an academic identity in Canadian rhetoric and composition. Phelps wrote, "It is difficult to compose a nationally viable identity around practices of instruction that are so decentered and disparate, lacking common pedagogical philosophies, habits, formats, or students" (p. 6). Phelps went on to conceptualize Canadian writing studies as an "intellectual movement looking for a place" (p. 6). That keynote was published in this journal in 2014 and these words are as true today as they were then.

This lack of "place" for writing scholars is both physical and metaphorical. It comes in the form of institutions situating writing faculty wherever it suits budget lines and institutional culture. It also shows up in features of Canadian institutions, such as the lack of graduate programs focusing on writing as a specialty, lack of tenured positions to support those programs, and the absence of a disciplinary category for writing, rhetoric, and composition within Canadian Tri-Council funding applications (Phelps, 2014). Many writing instructors and writing centre staff are faced with precarious employment and heavy workloads, reducing their ability to conduct writing research to an off-the-side-of-the-desk venture (Darroch et al., 2019). This reality, as Thieme (2019) articulated, leaves the field at "risk of being de-railed and de-disciplined" (p. 150) and, as Darroch et al. observed, excludes the voices of many who are responsible for supporting student writing.

In many ways, the history and the name of the journal have reflected an evolving understanding of its identity as a place for writing, and its relationship to the institutional lives of those who work in and speak on behalf of Canadian writing studies. The humble print newsletter Technostyle (19822008) became the Canadian Journal for the Study of Discourse and Writing/Rédactologie (2011-2020), 
Volume 32, 2022

http://journals.sfu.ca/dwr

which was in turn renamed Discourse and Writing/Rédactologie in 2021, with overwhelming support from CASDW members. While the name has changed, we continue to aspire to accommodate the research and scholarship of Canadian and a growing number of international scholars, and to serve as an intellectual common that houses those "decentered and disparate" thoughts and investigations that compose the identity of writing and discourse studies. The Canadian context is "uniquely local" (Phelps, 2014, p. 6), yet also internationally networked and theoretically driven. Discourse and Writing/Rédactologie continues to provide a place for "local" content while we invite a wider discussion beyond Canada and beyond genre studies.

We continue to welcome ideas about and approaches to writing that are difficult to place in more narrowly focused journals; $D W / R$ continues to be a "big tent," to quote our editorial predecessor Joel Heng-Hartse. We remain home to unique and timely calls for papers such as 2018's special issue on "Play, Visual Strategies, and Innovative Approaches to Graduate Writing," 2019's special issue on "Writing Instructors, Academic Labour, and Professional Development," 2020’s “Reflections on Genre as Social Action," and our forthcoming special issue on "Rethinking Structures of Academic Writing in Times of Exacerbated Inequity." We will also continue to feature in 2022 a series of outstanding essays adapted from papers presented at the Canadian Writing Centre Association's annual conference. Discourse and Writing/Rédactologie continues to act as an audit trail for thoughts on writing and discourse theory, the pedagogical practicalities of teaching writing, and the evolving landscape of writing studies in Canada and beyond.

With these reflections in mind, we will continue to consider how we can articulate the aims and scope of the journal to reflect our collective identity while continuing to value the need to embrace the diverse contexts of discourse and writing studies, both in Canada and internationally. We the editors, Kim Mitchell and Sean Zwagerman, are a complementary team whose disciplinary homes reflect the diffuse identity and the diverse locations of writing and discourse studies, with Sean a rhetorician in a university English department and Kim a faculty member of a nursing department in a polytechnic institution. We are drawn to different papers and bear strengths in different subfields and methodologies. We have made it a goal in our tenure as editors to begin the process of expanding the reach of the journal, through our recent listing on Erudit (https://www.erudit.org/en/iournals/dwr) and indexing through the Directory of Open Access Journals (https://doaj.org/toc/2563-7320). In addition to expanding the journal's audience exponentially, our membership in Erudit will see us making a small annual income which we will use to fund the graduate students we employ as our English and French Editorial Assistants. We continue 
Volume 32, 2022

http://journals.sfu.ca/dwr

to revise the journal's website (https://journals.sfu.ca/dwr/index.php/dwr/index) to make it fully bilingual, and all newly published papers will include abstracts in both English and French. We hope 2022 will bring our first Francophone publication since 2008. We have enhanced the involvement of our editorial board in establishing a vision for the future of the journal; the editorial board has been instrumental in crafting our recent special call for papers, and in revising and clarifying our guidelines for reviewers.

Being just short of two years at the helm, we feel we are finally starting to understand the journal, its identity, and its audience. And of course, our entire tenure to date has been impacted by the pandemic and its myriad exigencies and complications. We have yet to fully see what this pandemic era might contribute to the identity of our journal and Canadian writing studies, though we are receiving numerous submissions that see in the pandemic as an opportunity to reimagine writing pedagogy, a forward-looking vision for which $D W / R$ will continue to provide a home.

\section{References}

Darroch, H., Maftei, M., \& Humphreys, S. (2019). Writing instruction, academic labour, and professional development. Discourse and Writing/Rédactologie, 29(1), 133-136.

https://doi.org/10.31468/cjsdwr.817

Phelps, L. W. (2014). The historical formation of academic identities: Rhetoric and composition, discourse and writing. Discourse and Writing/Rédactologie, 25(1), 3-25.

https://doi.org/10.31468/cjsdwr.37

Thieme, K. (2019). Surface and depth: Metalanguage and professional development in Canadian writing studies. Discourse and Writing/Rédactologie, 29(1), 148-159.

\section{https://doi.org/10.31468/cjsdwr.757}

